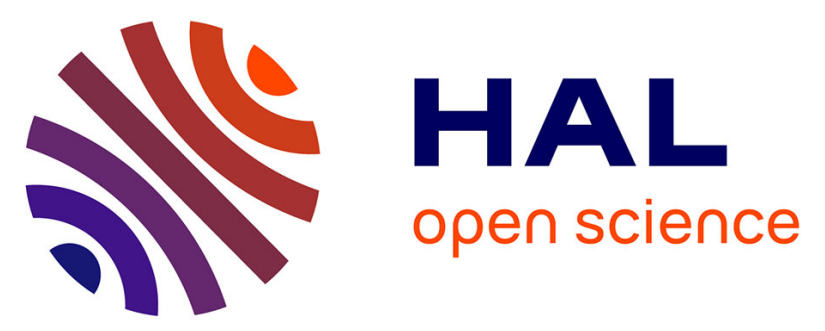

\title{
MASSIVE PARALLEL DNA PYROSEQUENCING ANALYSIS OF THE TUMOR SUPPRESSOR BRG1/SMARCA4 IN LUNG PRIMARY TUMORS
}

Salvador Rodriguez-Nieto, Andres Cañanda, Eva Pros, Ana Isabel Pinto, Juan

Torres-Lanzas, Fernando Lopez-Rios, Lydia Sanchez-Verde, David Pisano,

Montse Sanchez-Cespedes

\section{To cite this version:}

Salvador Rodriguez-Nieto, Andres Cañanda, Eva Pros, Ana Isabel Pinto, Juan Torres-Lanzas, et al.. MASSIVE PARALLEL DNA PYROSEQUENCING ANALYSIS OF THE TUMOR SUPPRESSOR BRG1/SMARCA4 IN LUNG PRIMARY TUMORS. Human Mutation, 2010, 32 (2), 10.1002/humu.21415 . hal-00613760

\section{HAL Id: hal-00613760 https://hal.science/hal-00613760}

Submitted on 6 Aug 2011

HAL is a multi-disciplinary open access archive for the deposit and dissemination of scientific research documents, whether they are published or not. The documents may come from teaching and research institutions in France or abroad, or from public or private research centers.
L'archive ouverte pluridisciplinaire HAL, est destinée au dépôt et à la diffusion de documents scientifiques de niveau recherche, publiés ou non, émanant des établissements d'enseignement et de recherche français ou étrangers, des laboratoires publics ou privés. 


\section{MASSIVE PARALLEL DNA PYROSEQUENCING ANALYSIS OF THE TUMOR SUPPRESSOR BRG1/SMARCA4 IN LUNG PRIMARY TUMORS}

\begin{tabular}{|c|c|}
\hline Journal: & Human Mutation \\
\hline Manuscript ID: & humu-2010-0351.R2 \\
\hline Wiley - Manuscript type: & Mutation in Brief \\
\hline $\begin{array}{r}\text { Date Submitted by the } \\
\text { Author: }\end{array}$ & $18-O c t-2010$ \\
\hline Complete List of Authors: & $\begin{array}{l}\text { Rodriguez-Nieto, Salvador; Institut Investigacions Biomediques } \\
\text { Bellvitge-IDIBELL, Cancer Epigenetics and Biology Program-PEBC } \\
\text { Cañanda, Andres; Spanish National Cancer Centre-CNIO, } \\
\text { Bioinformatics Unit } \\
\text { Pros, Eva; Institut Investigacions Biomediques Bellvitge-IDIBELL, } \\
\text { Cancer Epigenetics and Biology Program-PEBC } \\
\text { Pinto, Ana; Institut Investigacions Biomediques Bellvitge-IDIBELL, } \\
\text { Cancer Epigenetics and Biology Program-PEBC } \\
\text { Torres-Lanzas, Juan; Universitary Hospital "'Virgen de la Arrixaca, } \\
\text { Thoracic surgery Service } \\
\text { Lopez-Rios, Fernando; Centro Integral Oncologico Clara Campal, } \\
\text { Laboratorio de Dianas Terapeuticas } \\
\text { Sanchez-Verde, Lydia; Spanish National Cancer Centre-CNIO, } \\
\text { Inmunohistochemistry and Histology Unit } \\
\text { Pisano, David; Spanish National Cancer Centre-CNIO,' } \\
\text { Bioinformatics Unit } \\
\text { Sanchez-Cespedes, Montse; Institut Investigacions Biomediques } \\
\text { Bellvitge-IDIBELL, Cancer Epigenetics and Biology Program-PEBC }\end{array}$ \\
\hline Key Words: & $\begin{array}{l}\text { Deep sequencing, SMARCA4, lung cancer, tumor suppressor gene, } \\
\text { 454-Roche }\end{array}$ \\
\hline
\end{tabular}

\section{SCHOLARONE ${ }^{\text {Im }}$ \\ Manuscripts}




\title{
Massive parallel DNA pyrosequencing analysis of the tumor suppressor BRG1/SMARCA4 in lung primary tumors
}

OFFICIAL JOURNAL

\begin{abstract}
Salvador Rodriguez-Nieto¹, Andres Cañada², Eva Pros ${ }^{1}$, Ana I. Pinto¹, Juan Torres-Lanzas³, Fernando LopezRios $^{4}$, Lydia Sanchez-Verde 5 , David G. Pisano², Montse Sanchez-Cespedes ${ }^{*}$

${ }^{1}$ Genes and Cancer Group, Cancer Epigenetics and Biology Program-PEBC (IDIBELL), L'Hospitalet de Llobregat, Barcelona, Spain; ${ }^{2 B i o i n f o r m a t i c s ~ U n i t, ~ S p a n i s h ~ N a t i o n a l ~ C a n c e r ~ C e n t r e ~(C N I O), ~ M a d r i d, ~ S p a i n ; ~}{ }^{3}$ Thoracic Surgical Department, Hospital Virgen de la Arrixaca, Murcia, Spain; ${ }^{4}$ Hospital Universitario Madrid Sanchinarro, Laboratorio de Dianas Terapeuticas, Madrid, Spain; 5 Immunohistochemistry-Histology Unit, Spanish National Cancer Centre (CNIO), Madrid, Spain.
\end{abstract}

${ }^{*}$ Correspondence to Montse Sanchez-Cespedes, Genes and Cancer Group, Cancer Epigenetics and Biology Program-PEBC (IDIBELL), L'Hospitalet de Llobregat, Barcelona, Spain.

Phone: +34932607132; Fax: +349326072.19; E-mail: mscespedes@ idibell.cat

Short Title: Deep sequencing and SMARCA4 mutations in lung cancer.

Communicated by <Please don't enter>

\begin{abstract}
The tumor suppressor gene, SMARCA4 (or BRG1), which encodes the ATPase component of the chromatin remodeling complex SWI/SNF, is commonly inactivated by mutations and deletions in lung cancer cell lines. However, SMARCA4 alterations appear to be rare in lung primary tumors. Ultra-deep sequencing technologies provide a promising alternative to achieve a sensitivity superior to that of current sequencing strategies. Here we used ultra-deep pyrosequencing to screen for mutations over the entire SMARCA4 coding region in 12 lung tumors without detectable BRG1 protein. While automatic-fluorescence-based sequencing detected one somatic mutation (p.K586X), the pyrosequencing revealed additional variants, thus increasing the sensitivity. One of the variants, which affected a consensus splice site, was confirmed by individual cloning of PCR products, ruling out the possibility of PCR or pyrosequencing artifacts. This mutation, confirmed to be somatic, was present at a frequency of ten percent, suggesting normal cell contamination in the tumor. Our analysis also allowed us to determine the sensitivity and to identify some limitations of the technology. In conclusion, in addition to cell lines, SMARCA4 is biallelically inactivated in a significant proportion of lung primary tumors, thereby constituting one of the most important genes contributing to the development of this type of cancer. (O2010 Wiley-Liss, Inc.
\end{abstract}

KEY WORDS: Deep sequencing, SMARCA4, BRG1, lung cancer, tumor suppressor gene, 454-Roche

Received <date>; accepted revised manuscript <date $>$.

(C) 2010 WILEY-LISS, INC. 


\section{INTRODUCTION}

The accurate identification of the complete set of genes mutated in cancer is becoming increasingly important. This knowledge will serve not only to guide drug design but also to select patients who will benefit from new targeted therapies. The unavoidable presence of mixed non-malignant cells in primary tumor specimens in conjunction with the relatively low sensitivity of the fluorescence-based Sanger sequencing hamper the detection of point mutations, large deletions and indels [Ahrendt et al., 1999; Blanco et al., 2009]. We previously showed that the frequency of alterations detected in cancer genes in lung cancer cell lines is twice that in lung primary tumors, suggesting the existence of masked gene mutations in the latter [Blanco et al., 2009]. Therefore, if cancer patients are to take full advantage of new targeted treatments, this obstacle requires a prompt solution. The use of high-throughput sequencers may be useful for overcoming this hurdle. These instruments perform massive parallel sequencing and simultaneously analyze samples and sequences [Shendure and $\mathrm{Ji}, 2008$ ] and so may be able to detect minor gene variants. Massive parallel resequencing is proving to be especially useful for identifying gene variants in viruses of infected patients [Wang et al., 2007]. In cancer, deep resequencing has been used to detect low-prevalence mutations in cancer cells, including drug-resistance mutations from biopsies taken after relapse [Thomas et al., 2006], and to identify subclonal populations in leukemia patients [Campbell et al., 2008].

BRG1 is a central component of the SWI/SNF chromatin remodeling complex with a bromodomain and helicase/ATPase activity [Klochendler-Yeivin et al., 2002]. We reported a high incidence of inactivating mutations at SMARCA4 (also known as BRG1) (MIM\#603254), in lung cancer cell lines [Medina et al., 2008]. This is a very large gene that encodes a protein of 1,614 aminoacids. About a quarter of the cell lines screened featured SMARCA4 inactivation, making it the fifth most frequently mutated gene in non-small cell lung cancer (NSCLC) cell lines, the most common type of lung cancer. However, these observations contrasted with the seemingly low initial rate of inactivating mutations of SMARCA4 detected in lung primary tumors [Medina et al., 2004]. We hypothesize that many SMARCA4 mutations went undetected due to normal cell contamination of the tumor specimens. In support of this, two earlier studies used immunohistochemical staining to evaluate the levels of BRG1 in lung primary NSCLCs, and revealed that 30 percent of the tumors had no detectable protein [Reisman et al., 2003 and Fukuoka et al., 2004]. In the present work we used a PCR-based massive parallel pyrosequencing approach to search for mutations at SMARCA4 in lung primary tumors.

\section{METHODS}

\section{Patient selection, tissue microarray construction and immunostaining}

Formalin-fixed paraffin-embedded (FFPE) lung primary tumors and matching normal tissues were provided by the CNIO Tumour Bank Network, in collaboration with Spanish hospitals. The study was approved by the institutional review boards and ethics committees and informed consent was obtained from each patient. FFPE tissue blocks from lung primary tumors were used for tissue microarray construction, as previously described [Conde et al., 2006], and further processed for BRG1 immunohistochemical staining using the anti-BRG1 (H88) sc-10768 from Santa Cruz Biotechnology, at (1:15) dilution. The protocols used for immunostaining were those previously described [Conde et al., 2006]. Sections were counterstained with hematoxylin-eosin for quality evaluation. Finally, 12 adenocarcinomas with very low to null immunoreactivity for BRG1 upon double-blind analysis were selected for further studies. For genomic DNA extraction, freshly frozen tissue from tumors was meticulously dissected to ensure enriched material of at least $40 \%$ tumor cells. Approximately 10-20- $\mu \mathrm{m}$ sections were collected from normal and tumor samples and placed in $1 \%$ SDS/proteinase $\mathrm{K}(10 \mathrm{mg} / \mathrm{ml})$ at $58^{\circ} \mathrm{C}$ overnight. Digested tissue was then subjected to phenol-chloroform extraction and ethanol precipitation following standard procedures.

\section{PCR, vector cloning and Sanger sequencing}

All mutations or variations and their predicted effect at the protein level have been named according to the Human Genome Variation Society guidelines (http//:www.hgvs.org). The A of the ATG translation initiation codon corresponds to position +1 according to the SMARCA4 mRNA RefSeq EU_430759.1. For mutation screening of the SMARCA4 gene, exons 2 to 34 (NM_003072.3) were 
2

amplified from $30 \mathrm{ng}$ of genomic DNA extracted from the 12 selected tumors. All PCR reactions were carried out with the proofreading Phusion High-Fidelity polymerase (Finnzymes, Finland). In order to suit the read-length requirements for 454 pyrosequencing ( $250 \mathrm{bp}$ on each reading sense strand), exon 4 was divided into two amplicons. Also, the close proximity of exons 10 and 11 made it appropriate to merge them in a single amplicon. Thus, a total of 33 amplicons were obtained from each tumor sample. The sequences of the amplicons and the primers used are shown in the supplementary methods. The PCR products were sequenced individually by automatic Sanger sequencing and by 454-pyrosequencing (GS FLX System, Roche) (see below). Sanger sequencing of PCR products was carried out using the Big Dye Terminator cycle sequencing kit (Applied Biosystems, Foster City, CA) with an ABI PRISM 3700 DNA Analyzer (Applied Biosystems), according to the manufacturer's instructions. All the mutations found were confirmed with independent PCR products. To confirm the variants found by deep sequencing and to compare their frequencies, the purified PCR products were cloned in the pGEMT Easy Vector System (Promega, Madison, WI), following the manufacturer's instructions. Positive colonies were picked, grown and processed using the NucleoSpin Multi-96 Plus plasmid purification kit (Macherey Nagel, Düren, Germany). The purified products were sequenced using the Big Dye Terminator cycle sequencing kit, as described above, and the resulting sequences were aligned and analyzed using the BioEdit program (http://www.mbio.ncsu.edu/BioEdit/bioedit.html).

\section{Analysis of loss of heterozygosity}

The microsatellite markers selected to analyze loss of heterozygosity ( $\mathrm{LOH}$ ) on chromosome 19p were, from telomere to centromere: D19S886, D19S883, D19S586, D19S583, D19S221, D19S914. The latter four microsatellites flank the SMARCA4 locus while the former two flank $L K B 1$. The PCRs were performed using fluorescent-labeled primers and carried out according to the following protocol: $4 \mathrm{~min}$ at $94^{\circ} \mathrm{C}$ for initial denaturation; $30-32$ cycles at $94^{\circ} \mathrm{C}$ for $30 \mathrm{~s}, 55^{\circ} \mathrm{C}$ for $30 \mathrm{~s}$ and $72^{\circ} \mathrm{C}$ for $30 \mathrm{~s}$; then at $72^{\circ} \mathrm{C}$ for an additional $7 \mathrm{~min}$. PCR products were analyzed in an automated sequencer ABI PRISM 37130X1 (Applied Biosystems) using the GeneMapper 4.0 analytical program. For each microsatellite marker, the normal DNA sample was used to determine the allele size for the corresponding subject. Allele ratios were calculated following the manufacturer's instructions. Since incomplete allelic losses are commonly observed in heterogeneous tumor samples, ratio values $\leq 0.67$ or $\geq 1.35$ were considered to be unambiguously indicative of LOH. Homozygous cases were considered to be non-informative (NI) for $\mathrm{LOH}$.

\section{4 pyrosequencing}

The set of 12 tumor samples was divided into two groups, called LEFT and RIGHT, each containing six tumors. Thus, all amplicons from six tumors were lumped into two pools, the LEFT pool (tumors T01 to T06) and the RIGHT pool (tumors T07 to T12). The PCR products were individually quantified using the Quant-iT PicoGreen dsDNA reagent (Molecular Probes, Invitrogen). Mutation control amplicons were generated using the same primers and added to the amplicon pools. The controls, exon 5 from the cell line NCI-H522 carrying the frameshift mutation c.805_806delCC (generating a premature stop codon) and exon 16 from the cell line NCI-H2126 carrying the nucleotide substitution, c.2990T>A (p.W764R, affecting a highly conserved aminoacid) were amplified, generating the mutant amplicons E5mut and E16mut, respectively. The amplicons were quantified by PicoGreen and spiked into the pools equimolarly according to the following guideline: E16mut was spiked equimolarly into the LEFT pool without dilution and E5mut was mixed with normal E5 to a ratio of 1:50 and spiked equimolarly into the LEFT pool. Similarly, E5mut was spiked equimolarly into the RIGHT pool without dilution and E16mut was mixed with normal E16 to a ratio of 1:50 and spiked equimolarly into the RIGHT pool. The final pools containing all the amplicons from the tumors and the control cell lines were concentrated using Microcon YM-30 centrifugal filters (Millipore) and shipped for library construction and pyrosequencing. The pyrosequencing was conducted on a GS FLX sequencing platform (454 Life Sciences, CT, and Roche Applied Sciences, Indianapolis, IN) according to the manufacturer's 
instructions and using the suggested reagents. To this end, the amplicon pools were treated as fragmented genomic DNA. Briefly, a DNA library was prepared from the PCR fragments upon addition of adaptor sequences A and B (Digitags), which were captured and purified by streptavidin-biotin binding. Single-stranded template DNA (sstDNA) was then generated and the necessary amount of sstDNA molecules per bead was determined by a titration run. Single PCR amplicon molecules captured on individual beads were amplified in a second emulsion PCR (emPCR) process using universal primers that yields about $10^{7}$ copies of the input DNA molecule. The emulsion was then disrupted; the beads were isolated and loaded onto picotiter plates. Sequencing reactions were carried out by synthesis using ultra-deep pyrosequencing (Margulies et al., 2005) on a Genome Sequencer FLX instrument located at the Life Sequencing facility (Valencia, Spain) (www.lifesequencing.com), which provides a maximum of 100 million bases distributed in 400,000 high-quality reads.

\section{Deep sequencing data analysis}

To verify the sequencing process quality, the original 454 reads were queried (Tera-BLASTN, Decypher v7.6.2.1) against a custom database of contaminating sequences. Reads that matched with external organisms (significance threshold $=0.01$ ) were excluded from subsequent analyses. The GS Amplicon Variant Analyzer (AVA) v1.1.03 (454 Life Sciences) was used to align the deep sequencing reads against a reference made up of the sequences of all the amplicons (NM_003072.3) using the algorithm's default parameters. A total of 12 flowgrams (SFF format) were used as input. AVA software automatically trimmed the primers used to prepare the amplicon library where appropriate, combined the LEFT and RIGHT reads, and performed the alignments taking into account the base call qualities. We chose not to apply any filter value to the frequency of the reported variants to increase the number of candidates. Finally, the candidate changes were manually curated following the instructions in the program manual, taking into consideration coverage, bidirectional support for the variants, presence of homopolymers at the vicinity of the variant position and variant position in the read. All putative nucleotide changes with a frequency lower than the average noise level in the variation frequency plot were not considered. We also manually discarded variants with very low frequency (less than 1\%) that showed no other convincing evidence of relevance. Finally, the flowgrams for the remaining variations were visually inspected to assess the fidelity of the change.

\section{RESULTS}

\section{BRG1 immunostaining and fluorescence-based automatic sequencing in lung primary tumors}

We performed immunostaining for BRG1 in a panel of 122 lung primary tumors and found 46 (37\%) with very low to null levels of BRG1 that were considered negative for BRG1 protein immunostaining (Fig. 1A). These tumors were candidates for the presence of a biallelic inactivating mutation and/or deletion. The frequency of negative BRG1 immunostaining distributed similarly between the two main histopathological types of lung cancer (adenocarcinomas and squamous cell carcinomas). Subsequently, we selected 12 of the lung tumors with negative BRG1 immunostaining to screen for mutations at each of the coding exons and at the intron-exon boundaries using fluorescence-based automatic Sanger sequencing. In addition to negative for BRG1 immunostaining the tumors were selected on the basis of availability for matched normal DNA. We found a single mutation at exon 10, an A $>$ T nucleotide substitution predicting a change from the lysine at position 586 to a stop codon (Fig. 1B). Several known single nucleotide polymorphisms (SNPs) were also observed (Table 1).

In addition, we analyzed loss of heterozygosity $(\mathrm{LOH})$ using six microsatellite markers spanning 10 $\mathrm{Mb}$ in the short arm of chromosome 19p. Four of them surrounded the SMARCA4 locus and two were close to the STK11 locus, another tumor suppressor gene frequently inactivated in lung cancer. The results are shown in Figure 1C. Information about gene alterations in other known cancer genes i.e. TP53 (MIM\#191170), STK11 (MIM\#602216), KRAS (MIM\#190070) and EGFR (MIM\#131550), is also provided for these tumors. Six (50\%) of the tumors had clear LOH in the markers near SMARCA4, and 
2

also had mutations at one or more cancer genes, indicating that normal cell contamination was low in these specimens. Three of the tumors, negative for $\mathrm{LOH}$, exhibited allele ratios close to the cut-off values (data not shown) and no mutations at other genes, implying a masking effect due to normal cell contamination or to tumor heterogeneity. The remaining tumors did not feature $\mathrm{LOH}$, but were positive for mutations at other genes. Clear LOH surrounding the SMARCA4 locus was found in the SMARCA4mutant tumor identified by Sanger sequencing (Fig. 1C). This indicates the loss of the remaining normal allele and so the homozygous nature of the mutation, thus supporting the two-hit hypothesis [Knudson 1971].

A

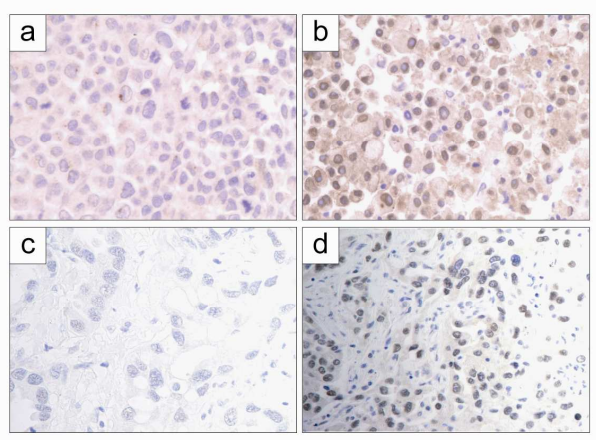

B

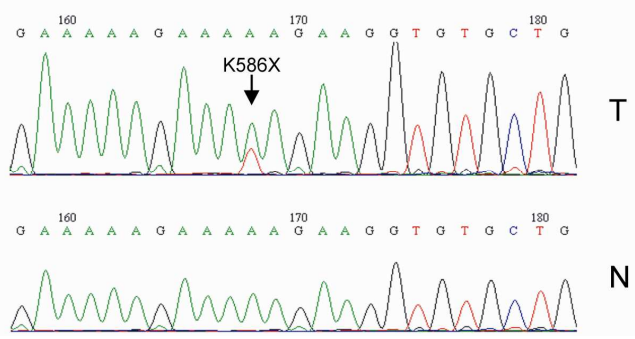

C

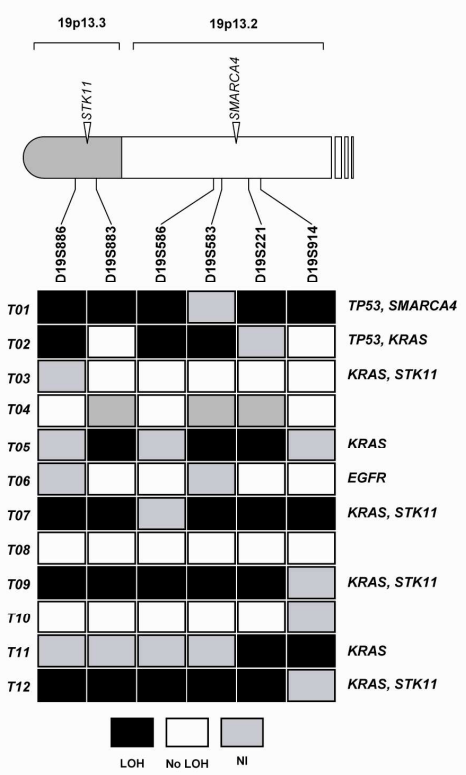

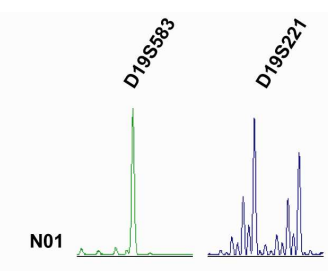

ro1
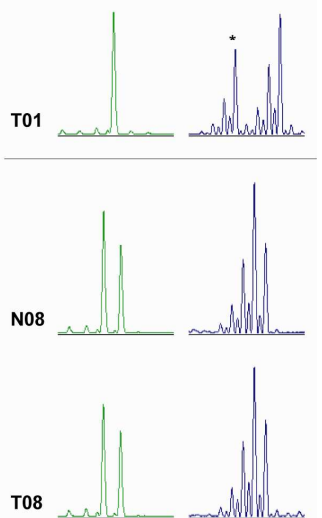

Figure 1. SMARCA4 alterations in lung cancer. (A) Representative examples of BRG1 positive and negative immunostaining in lung cancer cell lines (a, cell line NCl-H23 harboring the nonsense mutation E1533X; b, wild type cell line $\mathrm{NCl}-\mathrm{H} 1395$ ) and lung primary tumors ( $\mathrm{c}$ and d, primary tumors negatively and positively stained for BRG1, respectively). Original magnification, 400x. (B) Example of the nonsense mutation (p.K586X) in a lung primary tumor (T01) compared with matched normal tissue $(\mathrm{N})$ as detected by Sanger sequencing. (C) Loss of heterozygosity ( $\mathrm{LOH}$ ) on chromosome arm 19p was analyzed using the indicated microsatellite markers flanking SMARCA4 (band 19p13.2) and STK11 (band 19p13.3) loci in the panel of lung primary tumors used in the study. Mutation status of those tumors for other genes is also indicated. NI, noninformative. On the right are examples of the $\mathrm{LOH}$ analysis using the indicated microsatellites and tumor samples. The asterisk indicates the $\mathrm{LOH}$.

\section{Deep resequencing of the coding region of SMARCA4 in lung primary tumors}

We have previously reported that lung cancer cell lines bear about twice as many mutations at any known cancer gene as do lung primary tumors [Blanco et al., 2009]. The low frequency of mutations at SMARCA4 in lung primary tumors compared with lung cancer cell lines is probably a consequence of normal cell contamination in conjunction with the low sensitivity of current sequencing approaches. To investigate the possible presence of mutations that had not been detected in the automatic Sanger sequencing analysis, we took a deep-resequencing approach using the 454-FLXs machine (Roche Diagnostics). SMARCA4 is a very large gene, with an open reading frame of 4,845 bp distributed among 33 coding exons. We amplified each of these exons using a high-fidelity proofreading polymerase, thereby obtaining 33 different amplicons. Due to the large number of amplicons we avoided using barcodes in the primers to identify individual tumors. Instead, we pooled the amplicons to construct two independent libraries for massive parallel sequencing (see methods for details). 


\section{Rodriguez-Nieto et al.}

A

Genomic DNA from BRG1-negative lung primary tumors

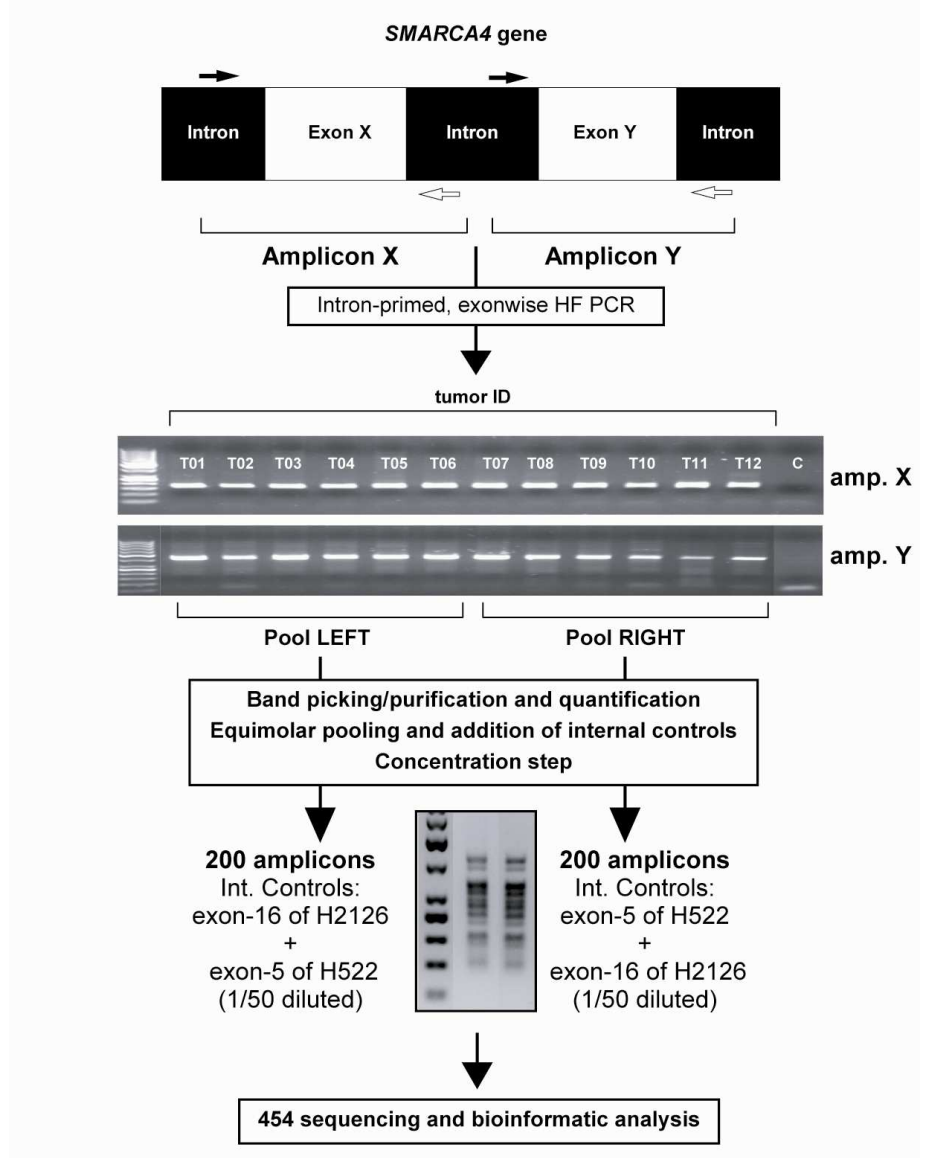

B

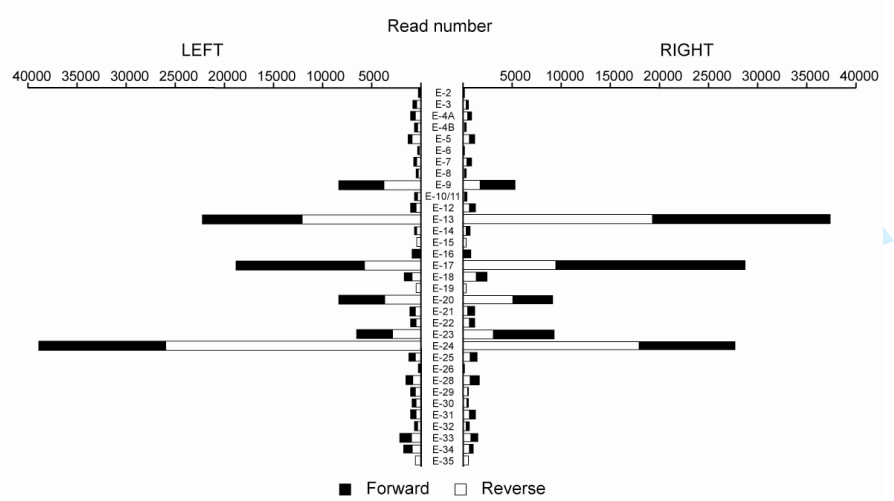

Figure 2. Workflow and 454 output. (A) Intron-primed, exon wise high-fidelity PCR amplification of SMARCA4 from genomic DNA obtained from 12 selected BRG1-negative lung primary tumors (T01 to T12). PCR products were separated in agarose gels and the specific bands were cut out and purified. The purified amplicons from all of the tumors were quantified and mixed equimolarly in two independent pools (LEFT and RIGHT, containing all SMARCA4 exons of tumors T01 to T06, and tumors T07 to T12, respectively). Each pool was spiked with control amplicons (see methods for details). The panel at the bottom shows an agarose gel separation of the final concentrated pools. (B) Plot representing the total number of reads in forward and reverse, for each of the exons within each pool of amplicons generated by 454 deep sequencing. 
2

Each of the two pools contained the entire coding sequence and the intron-exon boundaries of the SMARCA4 gene (8,351-bp; Supp. Methods) from six separate tumor samples. To measure the accuracy and sensitivity of the assay we included two control amplicons consisting of two known mutations from lung cancer cell lines (c.805_806delCC from NCI-H522 and c.2290T>A from NCI-H2126) previously identified in our laboratory [Medina et al., 2008]. The amplicons containing each mutation were included in the pools without prior dilution or diluted at 1:50 with normal blood DNA. A schematic representation of the approach and the length of each amplicon are depicted in Figure 2A and in the Supplementary Methods, respectively. Our approach was designed to provide 1,000 reads per individual amplicon.

The analysis yielded a total of 346,951 sequences, of which 260,000 (75\%) mapped to the reference sequence of SMARCA4 (127,247 for LEFT and 139,753 for RIGHT). The rest were products unrelated to SMARCA4, probably non-specifically amplified during the PCR process. About 50.5\% of the reads were on forward and $49.5 \%$ were on reverse sense strands. The number of reads per amplicon in each pool was highly variable, ranging from about 130 to 37,000 (Fig. 2B and Supp. Table S1). As depicted, amplicons 2, 6 and 26 had the fewest reads (ranging from 128 to 354) followed by amplicons 4B, 8, 10-11, 15 and 19, with 283 to 618 reads. More than half of the amplicons (about eighteen) gave over 1,000 reads (six had more than 5,000) per amplicon in each pool, which ensures a sensitivity of $5 \%$ and $1 \%$, respectively, according to the manufacture's indications for single base changes and multibase deletions.

\section{SMARCA4 mutations and other variants identified by ultra-deep resequencing analysis}

All the variants detected by Sanger sequencing were called in the 454-pyrosequencing data, including all the germ-line SNPs and a nonsense mutation (c.1756A $>$ T) (Table 1). The controls included in the analysis without prior dilution were also evident in their respective pools. In addition to known variants, there were many small insertions and deletions, especially in homopolymeric tracts. These probably correspond to artifacts that arose during pyrosequencing; difficulties in resolving this type of sequence are well known [Campbell et al., 2008]. Other changes, mainly nucleotide substitutions, were also evident and could have been artifacts arising during the $\mathrm{PCR} /$ sequencing processes or true mutations.

The control mutations and the SNPs in the study allowed us to calculate the approximate sensitivity of the pyrosequencing and the distribution of the PCR products from the distinct individuals. The c.2290T>A mutation control was detected in the LEFT pool at a combined frequency of $7 \%$, which was within the range of expected frequencies (7-14\%) (Supp. Table S2). The same mutation in the RIGHT pool had an expected frequency of 0.15$0.3 \%$, so although the observed frequency $(0.14 \%)$ was very close, it was below the lower cut-off value to qualify as a mutation. Likewise, the c.805_806delCC was found at 5.3\% in the RIGHT pool, close to the range of expected frequencies (7-14\%) while it was not found (0\%) in the LEFT pool. The observed frequencies of SNPs were close to the expected value, according to the observations from the Sanger sequencing (Supp. Table S2). Taken together, these observations imply that while the pool contains an unequal distribution of the various amplicons, the distribution of the same exons among different individuals is very similar.

We established the following arbitrary criteria to select those changes that were candidates for tumor-associated mutations: i) changes with a frequency greater than or equal to $0.5,1$ or $5 \%$, depending on the number of reads for a given amplicon (i.e., $0.5 \%$ for amplicons with $\geq 15,000$ reads, $1 \%$ for amplicons with $\geq 300$ reads and $5 \%$ for amplicons with $<300$ reads). These thresholds were only valid for nucleotide substitutions in nonhomopolymeric regions; ii) changes that appeared in both the forward and reverse reads; and iii) changes that appeared in only one of the tumor pools. All the changes that fulfilled these criteria are listed in Table 1; the variants included known polymorphisms, the mutation controls and the mutation detected by Sanger sequencing. The remaining changes were considered to be candidate mutations, some of which were explored further.

\section{Conventional cloning of PCR products and subsequent Sanger sequencing confirmed some variants found in the 454- pyrosequencing}

To determine whether the alterations identified were true mutations or artifacts arising during the PCR or the pyrosequencing process we selected some of the candidate mutations (Table 1) and subcloned the amplicons for each of the tumors within a given pool. We then performed Sanger sequencing in no fewer than 80 clones per tumor. When an alteration was confirmed, we independently repeated the PCR, in the specific tumor DNA, and subcloned again to verify the presence of the mutations and to discard any PCR errors. 
Table 1. List of all the variants fulfilling our criteria, detected at SMARCA4 using 454-pyrosequencing. The location according to mRNA Ref. Seq. EU430759.1 and the predicted change in the protein are indicated. SNPs and control mutations are also included. Total reads refers to the total number of reads for the indicated position in the LEFT and the RIGHT pools. \% variants refers to the percentage of variants detected with respect to the total number of reads at that position.

\begin{tabular}{|c|c|c|c|c|c|c|c|c|}
\hline \multirow[b]{2}{*}{ Exon/Intron } & \multicolumn{2}{|c|}{ LEFT } & \multicolumn{2}{|c|}{ RIGHT } & \multirow{2}{*}{$\begin{array}{l}\text { Nucleotide } \\
\text { Change }\end{array}$} & \multirow{2}{*}{$\begin{array}{c}\text { Predicted } \\
\text { effect }\end{array}$} & \multirow[b]{2}{*}{ Status } & \multirow{2}{*}{$\begin{array}{c}\text { Detected } \\
\text { Sanger }\end{array}$} \\
\hline & $\begin{array}{c}\% \% \\
\text { variants }\end{array}$ & $\begin{array}{l}\text { Total } \\
\text { reads }\end{array}$ & $\begin{array}{c}\% \% \\
\text { variants }^{1}\end{array}$ & $\begin{array}{l}\text { Total } \\
\text { reads }\end{array}$ & & & & \\
\hline I2 & 22.8 & 394 & 0 & 321 & c. $223-53 \mathrm{~T}>\mathrm{C}$ & None & SNP & yes \\
\hline $\mathrm{I} 3$ & 15.7 & 708 & 0 & 772 & c. $356-14 \mathrm{~A}>\mathrm{G}$ & None & SNP & yes \\
\hline E5 & 0 & 1162 & 5.3 & 1119 & c.805_806delCC & p.P270fs & $\begin{array}{l}\text { Control } \\
\text { mutation }\end{array}$ & NA \\
\hline E8 & 19 & 279 & 0.9 & 224 & c. $1413 \mathrm{G}>\mathrm{A}$ & p.K471K & SNP & yes \\
\hline E9 & 16.6 & 7389 & 0.04 & 4918 & c. $1509 A>G$ & p.A503A & SNP & yes \\
\hline E9 & 48.3 & 7354 & 20 & 4919 & c. $1524 \mathrm{~T}>\mathrm{C}$ & p.H508H & SNP & yes \\
\hline E10 & 6.4 & 373 & 0 & 317 & c. $1756 \mathrm{~A}>\mathrm{T}$ & p.K586X & $\begin{array}{l}\text { Somatic } \\
\text { mutation }\end{array}$ & yes \\
\hline $\mathrm{I} 10$ & 12.3 & 381 & 0 & 312 & c. $1761+29 \mathrm{G}>\mathrm{A}$ & None & SNP & yes \\
\hline I10 & 46 & 287 & 13 & 177 & c. $1762-37 \mathrm{~T}>\mathrm{C}$ & None & SNP & yes \\
\hline I14 & 22 & 578 & 0 & 655 & c. $2123+12 \mathrm{C}>\mathrm{T}$ & None & SNP & yes \\
\hline E15 & 1.06 & 378 & 0 & 286 & c. $2141 \mathrm{~T}>\mathrm{C}$ & p.V714A & $\begin{array}{l}\text { Candidate } \\
\text { mutation }\end{array}$ & no \\
\hline E16 & 7 & 711 & 0.14 & 732 & c. $2290 \mathrm{~T}>\mathrm{A}$ & p.W764R & $\begin{array}{l}\text { Control } \\
\text { mutation }\end{array}$ & NA \\
\hline E16 & 1.4 & 733 & 0 & 733 & c. $2315 \mathrm{~A}>\mathrm{G}$ & p.N772S & $\begin{array}{l}\text { Candidate } \\
\text { mutation }\end{array}$ & no \\
\hline I17 & 0.01 & 18291 & 1.8 & 28664 & c. $2505+2 \mathrm{~T}>\mathrm{C}$ & $\begin{array}{l}\text { Abnormal } \\
\text { splicing }\end{array}$ & $\begin{array}{l}\text { Candidate } \\
\text { mutation }\end{array}$ & no \\
\hline E28 & 0.5 & 905 & 16 & 493 & c. $3954 C>T$ & p.D1318D & SNP & yes \\
\hline E29 & 0 & 478 & 1.2 & 493 & c. $4192 \mathrm{C}>\mathrm{A}$ & p.R1398S & $\begin{array}{l}\text { Candidate } \\
\text { mutation }\end{array}$ & no \\
\hline E31 & 6 & 634 & 0 & 588 & c. $4485 \mathrm{C}>\mathrm{T}$ & p.D1495D & SNP & yes \\
\hline E33 & 59 & 1341 & 20.5 & 919 & c. $4788 \mathrm{~T}>\mathrm{C}$ & p.D1596D & SNP & yes \\
\hline
\end{tabular}

SNP, single nucleotide polymorphism previously reported in [Medina et al., 2008] or unpublished observations. ${ }^{1}$ Only changes found in a frequency between $0.5-5 \%$, depending on the number of reads for a given amplicon (i.e., $0.5 \%$ for amplicons with $\geq 15,000$ reads; $1 \%$ for amplicons with $\geq 300$ reads and $5 \%$ for amplicons with less than 300 reads). These thresholds were only used for nucleotide substitutions outside repetitive sequences. Small indels were not considered in our analysis.

The following changes were chosen for verification: c.2505+2T>C, c.2141T $>C$ and c.4192C $>$ A. Overall, we individually cloned 18 amplicons and obtained about 1,500 individual sequences. Two of the variants were confirmed in the analysis and, therefore, assigned to a given tumor. However, one of them (c.2141T>C) was not found in any of the tumors during the conventional cloning of the PCR products. We cannot rule out the possibility that this is a true inactivating mutation with a frequency below the threshold of detection of the assay. On the other hand, the other two mutations, c. $2505+2 \mathrm{~T}>\mathrm{C}$ and c.4192C $>\mathrm{A}$, were confirmed in the first cloning but only c. $2505+2 \mathrm{~T}>\mathrm{C}$ was verified in the second, independent subcloning. This suggests that $\mathrm{c} .4192 \mathrm{C}>\mathrm{A}$ arose during the PCR. Table 2 summarizes the results and Figure 3 depicts the analysis of the c. $2505+2 \mathrm{~T}>\mathrm{C}$ mutation detected by pyrosequencing and verified by individual cloning of the PCR products (Figs. 3A-B). 
2

Table 2. Selected candidate SMARCA4 mutations were tested for verification by conventional cloning of PCR products in each of the tumors in the assigned pool. At least 80 clones per PCR product were sequenced. The first verification was performed with the same PCR product as used in the deep sequencing while the second is an independent PCR product.

\begin{tabular}{|llllllll|}
\hline $\begin{array}{c}\text { Nucleotide } \\
\text { change }\end{array}$ & $\begin{array}{c}\text { Observed frequency } \\
\text { in pool }\end{array}$ & $\begin{array}{c}\text { Expected } \\
\text { frequency per } \\
\text { tumor }\end{array}$ & $\begin{array}{c}\text { First } \\
\text { verification }\end{array}$ & $\begin{array}{c}\text { Second } \\
\text { verification }\end{array}$ & $\begin{array}{c}\text { Sample } \\
\text { ID }\end{array}$ & LOH & Diagnostic \\
\hline c.2141T $>\mathrm{C}$ & $1.06 \%$ & $6.36 \%$ & No & NA & NA & NA & Unknown \\
c. $2505+2 \mathrm{~T}>\mathrm{C}$ & $1.8 \%$ & $11 \%$ & $\begin{array}{l}\text { Yes } \\
(9 / 90,10 \%)\end{array}$ & Yes & T08 & Yes & $\begin{array}{l}\text { Somatic } \\
\text { mutation }\end{array}$ \\
c.4192C $>\mathrm{A}$ & $1.2 \%$ & $7.2 \%$ & $\begin{array}{l}\text { Yes } \\
(4 / 88,4.5 \%)\end{array}$ & No $(0 / 160)$ & T11 & Yes & PCR error \\
\hline
\end{tabular}

NA, not applicable, the mutation could not be confirmed in the first verification; $\mathrm{LOH}$, loss of heterozygosity.

This mutation was confirmed to be present at a frequency of about $11 \%$, which is below the reported threshold for mutation detection by fluorescence Sanger sequencing. The tumor carrying the mutation (T08) was negative for mutations at other genes (Fig. 1C) and had no clear LOH, suggesting more than $75 \%$ normal cell contamination. This mutation was not present in the matched normal DNA, thus indicating a tumor specific alteration.

A

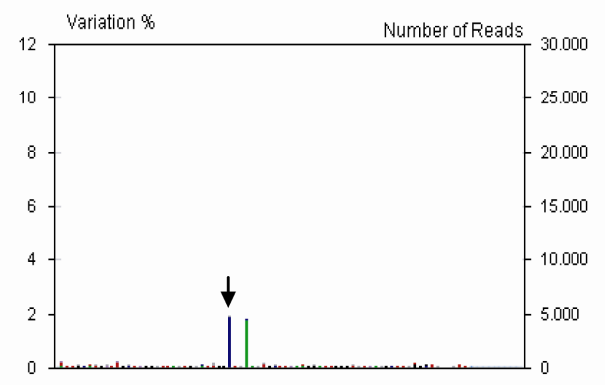

B

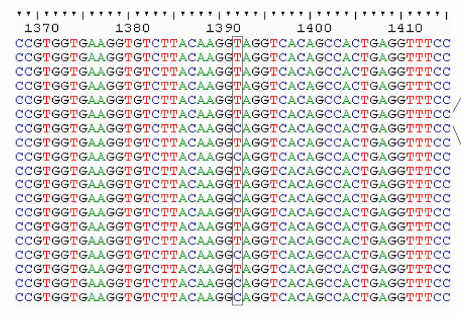

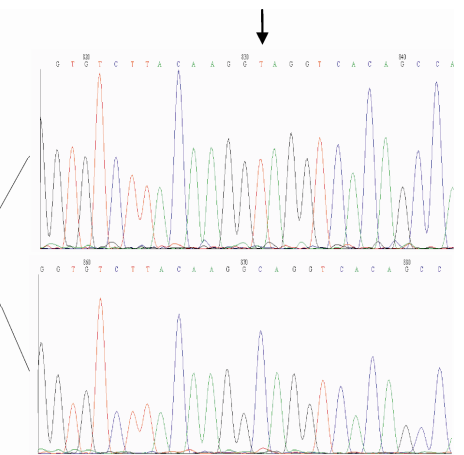

Figure 3. Analysis of a nucleotide substitution found by pyrosequencing. (A) Variation plot analysis of SMARCA4 amplicon 17, where a substitution mutation at the donor splice site of intron 17 (c.2405+2T>C) was detected at a relative allele frequency of approximately $2 \%$ (arrow). (B) Sequencing and alignment of individual bacterial clones transformed with amplicon 17 assigned the mutation to T08 and provided information about its relative frequency. (C) chromatograms confirming the c. $2405+2 T>C$ mutation during the cloning of an independent PCR product.

\section{DISCUSSION}

BRG1 is a catalytic component of the SWI/SNF chromatin-remodeling complex and regulates gene expression by disrupting histone-DNA contacts in an ATP-dependent manner [Roberts and Orkin 2004]. Several lines of evidence attest to the importance of BRG1 in tumor development. Brgl-heterozygous mice have a marked predisposition to develop tumors [Bultman et al., 2000], BRG1 induces cell-growth arrest after ectopic expression in BRG1-deficient tumor cells alone or after co-expression with p16 or RB [Reisman et al., 2002; Kang et al., 2004] and it binds to significant tumor suppressor proteins, including BRCA2 [Bochar et al., 2000]. More recently, SMARCA4 germ-line mutations have been associated with a cancer prone disease, the rhabdoid tumor predisposition syndrome [Schneppenheim et al., 2010], further demonstrating that SMARCA4 is a bona fide tumor suppressor. Wong et al. reported the presence of SMARCA4 homozygous intragenic deletions and a concomitant absence of protein in some cancer cells lines [Wong et al., 2000] and we also found that 30 percent of the lung cancer cell lines carry a SMARCA4 biallelic inactivation. In spite of the high frequency of SMARCA4-inactivating mutations in lung cancer cell lines, in lung primary tumors we reported a rare presence of SMARCA4 mutations [Medina et al., 2004]. Detection of somatic mutations in primary tumors has mostly been based on fluorescence- 
based Sanger sequencing but the sensitivity of this approach is clearly poor (it rarely detects variants frequencies of $<20 \%$ ) [Wang et al., 2007].

Here we show that massive parallel sequencing increases the rate of mutation detection in SMARCA4 in lung primary tumors by at least eight percent relative to automatic fluorescence-based methods. Consistent with our present observations, Thomas and collaborators used deep pyrosequencing to screen for EGFR mutations in lung primary tumors and reported a 15 percent increase in the number of mutations compared with those identified by Sanger sequencing [Thomas et al., 2006]. They also detected the presence of mutations in low tumor content lung cancer biopsies, detecting a mutation with a prevalence of two percent in approximately 137,000 reads. This implies that, despite selecting specimens for high tumor cell content, normal cell contamination hinders mutation detection. In our study we selected specimens with a tumor cell content of over $40 \%$. However, tumor cell content evaluation performed microscopically cannot be extrapolated to the tumor cell content in the same specimen subjected to DNA and RNA extraction.

Overall we found inactivating and biallelic mutations at SMARCA4 in our selected group of lung primary tumors, confirming that SMARCA4 is a major tumor suppressor gene in lung cancer. These are likely inactivating mutations because predict truncated proteins and lead to the absence of BRG1 protein, undetectable by immunostaining. Nevertheless, we expect to have underestimated the frequency of SMARCA4 gene alterations. Large intragenic deletions are undetectable by this approach but account for about $20 \%$ of the alterations at SMARCA4 in lung cancer cell lines [Medina et al., 2008]. Moreover, mutations in homopolymeric tracts, a type of alteration commonly found in lung cancer cell lines, were excluded from our analysis because they are highly prone to pyrosequencing artifacts [Campbell et al., 2008]. This type of alteration may also have been missed. Another limitation of our approach is the unequal depth of coverage among different exons. This is a general problem when pooling different amplicons for deep sequencing, as noted by others [Qin et al., 2010; Rohlin et al., 2009], and is attributable to amplification bias affecting product yield. These drawbacks need to be carefully considered when using pyrosequencing to search for mutations, especially in tumor suppressor genes, since these are often altered through large deletions and indels within repetitive sequences. An additional limitation to increased sensitivity is the generation of mutations by DNA polymerases during the PCR [Campbell et al., 2008], although this could be solved using exon-capturing approaches that avoid prior PCR. Exon-capturing has other advantages such as its amenability to simultaneously selecting multiple exons of various genes, which facilitates rapid screening for mutations [Choi et al., 2009; Lalonde et al., 2010]. Even so, these new strategies will not serve to detect the presence of large intragenic deletions in tumor suppressor genes, for which additional screening methods will be required.

In the present analysis we performed deep sequencing of a pool of PCR products from 400 individual amplicons containing the entire coding region of SMARCA4. The enhanced efficacy of pooling PCR products over prior pooling of genomic DNA was demonstrated by Out and collaborators [Out et al., 2009], who compared the reliability of deep sequencing after pooling 287 genomic DNAs from tumor samples and subsequently performed long-range PCR of the pooled sample and compared the results with those from a PCR of 88 individual samples whose products were then pooled. They observed that the correlations of the allelic frequencies with the results of the Sanger sequencing were significantly weaker in the former, probably due to differences in the integrity of the genomic DNA in the individual tumor samples. Here we found that the control mutations and the SNPs were within the range of expected frequencies, indicating that the identical PCR products from different individuals were similarly distributed in the pool. This indicates that within the conditions of our experimental design, the pooling of identical amplicons does not affect the sensitivity of the approach, as compared to the use of bar-coded amplicons. As well as identifying novel mutations undetected by Sanger sequencing, pyrosequencing analysis was able to identify all the variants detected by fluorescence Sanger sequencing, including the germ-line polymorphisms and the mutation controls.

In conclusion, the present work is one of only few to report the use of deep sequencing to search for lowprevalence mutations in human cancer. We demonstrated that, like in lung cancer cell lines, homozygous SMARCA4 mutations are present in lung primary tumors. The use of massive parallel pyrosequencing was more sensitive for detecting mutations than fluorescence Sanger sequencing and is, therefore, a promising tool for mutation screening in mixed populations. 
We acknowledge the technical assistance of Albert Coll from the Genes and Cancer Group (PEBC). We thank and acknowledge the technical help our colleagues at the Immunohistochemistry/Histology, Genomics and Tumour Bank Units of the Spanish National Cancer Centre (CNIO) and the Tumour Bank of the Virgen de la Arrixaca Hospital, Murcia (to Susana Nieto Cerón). We also thank the support of the National Institute for Bioinformatics (www.inab.org), a platform of 'Instituto de Salud Carlos III' to DGP and AC.

Grant Support: The work was supported by grants from the Spanish Ministerio de Ciencia e Innovación (MICINN) (SAF2008-02698) to MS-C, and RTICCs (RD06/0020/0023, RD06/0020/0062) to M.S-C and JT-L. SR-N is the recipient of a contract from the Asociación Española Contra el Cancer (AECC).

\section{COMPETING INTERESTS STATEMENT}

The authors declare that they have no competing financial interests.

\section{REFERENCES}

Ahrendt SA, Halachmi S, Chow JT, Wu L, Halachmi N, Yang SC, Wehage S, Jen J, Sidransky D. 1999. Rapid p53 sequence analysis in primary lung cancer using an oligonucleotide probe array. Proc Natl Acad Sci USA 96:7382-7387.

Blanco R, Iwakawa R, Tang M, Kohno T, Angulo B, Pio R, Montuenga LM, Minna JD, Yokota J, Sanchez-Cespedes M. 2009. A gene-alteration profile of human lung cancer cell lines. Hum Mutat 30:1199-1206.

Bochar DA, Wang L, Beniya H, Kinev A, Xue Y, Lane WS, Wang W, Kashanchi F, Shiekhattar R. 2000. BRCA1 is associated with a human SWI/SNF-related complex: linking chromatin remodeling to breast cancer. Cell 102:257-265.

Bultman S, Gebuhr T, Yee D, La Mantia C, Nicholson J, Gilliam A, Randazzo F, Metzger D, Chambon P, Crabtree G, Magnuson T. 2000. A Brg1 null mutation in the mouse reveals functional differences among mammalian SWI/SNF complexes. Mol Cell 6:1287-1295.

Campbell PJ, Pleasance ED, Stephens PJ, Dicks E, Rance R, Goodhead I, Follows GA, Green AR, Futreal PA, Stratton MR. 2008. Subclonal phylogenetic structures in cancer revealed by ultra-deep sequencing. Proc Natl Acad Sci U S A 105:1308113086.

Choi M, Scholl UI, Ji W, Liu T, Tikhonova IR, Zumbo P, Nayir A, Bakkaloglu A, Ozen S, Sanjad S, Nelson-Williams C, Farhi A, Mane S, Lifton RP. 2009. Genetic diagnosis by whole exome capture and massively parallel DNA sequencing. Proc Natl Acad Sci USA 106:19096-19101.

Conde E, Angulo B, Tang M, Morente M, Torres-Lanzas J, Lopez-Encuentra A, Lopez-Rios F, Sanchez-Cespedes M. 2006. Molecular context of the EGFR mutations: evidence for the activation of mTOR/S6K signaling. Clin Cancer Res 12:710717.

Fukuoka J, Fujii T, Shih JH, Dracheva T, Meerzaman D, Player A, Hong K, Settnek S, Gupta A, Buetow K, Hewitt S, Travis WD, Jen J. 2004. Chromatin remodeling factors and BRM/BRG1 expression as prognostic indicators in non-small cell lung cancer. Clin Cancer Res 10:4314-4324.

Kang H, Cui K, Zhao K. 2004. BRG1 controls the activity of the retinoblastoma protein via regulation of p21CIP1/WAF1/SDI. Mol Cell Biol 24:1188-1199.

Klochendler-Yeivin A, Muchardt C, Yaniv M. 2002. SWI/SNF chromatin remodeling and cancer. Curr Opin Genet Dev 12:7379.

Knudson AG, Jr. 1971. Mutation and cancer: statistical study of retinoblastoma. Proc Natl Acad Sci USA 68:820-823.

Lalonde E, Albrecht S, Ha KC, Jacob K, Bolduc N, Polychronakos C, Dechelotte P, Majewski J, Jabado N. 2010. Unexpected allelic heterogeneity and spectrum of mutations in Fowler syndrome revealed by next-generation exome sequencing. Hum Mutat. Jun 1. [Epub ahead of print] 
Margulies M, Egholm M, Altman WE, Attiya S, Bader JS, Bemben LA, Berka J, Braverman MS, Chen YJ, Chen Z, Dewell SB, Du L, Fierro JM, Gomes XV, Godwin BC, He W, Helgesen S, Ho CH, Irzyk GP, Jando SC, Alenquer ML, Jarvie TP, Jirage KB, Kim JB, Knight JR, Lanza JR, Leamon JH, Lefkowitz SM, Lei M, Li J, Lohman KL, Lu H, Makhijani VB, McDade KE, McKenna MP, Myers EW, Nickerson E, Nobile JR, Plant R, Puc BP, Ronan MT, Roth GT, Sarkis GJ, Simons JF, Simpson JW, Srinivasan M, Tartaro KR, Tomasz A, Vogt KA, Volkmer GA, Wang SH, Wang Y, Weiner MP, Yu P, Begley RF, Rothberg JM. 2005. Genome sequencing in microfabricated high-density picolitre reactors._Nature 437:376-380.

Medina PP, Carretero J, Fraga MF, Esteller M, Sidransky D, Sanchez-Cespedes M. 2004. Genetic and epigenetic screening for gene alterations of the chromatin-remodeling factor, SMARCA4/BRG1 in lung tumors. Genes Chrom Cancer 41:170-177.

Medina PP, Romero OA, Kohno T, Montuenga LM, Pio R, Yokota J, Sanchez-Cespedes M. 2008. Frequent BRG1/SMARCA4-inactivating mutations in human lung cancer cell lines. Hum Mutat 29:617-622.

Out AA, van Minderhout IJ, Goeman JJ, Ariyurek Y, Ossowski S, Schneeberger K, Weigel D, van Galen M, Taschner PE, Tops CM, Breuning MH, van Ommen GJ, den Dunnen JT, Devilee P, Hes FJ. 2009. Deep sequencing to reveal new variants in pooled DNA samples. Hum Mutat 30:1703-1712.

Qin W, Kozlowski P, Taillon BE, Bouffard P, Holmes AJ, Janne P, Camposano S, Thiele E, Franz D, Kwiatkowski DJ. 2010. Ultra deep sequencing detects a low rate of mosaic mutations in tuberous sclerosis complex. Hum Genet 127:573-582.

Reisman DN, Strobeck MW, Betz BL, Sciariotta J, Funkhouser W, Jr., Murchardt C, Yaniv M, Sherman LS, Knudsen ES, Weissman BE. 2002. Concomitant down-regulation of BRM and BRG1 in human tumor cell lines: differential effects on RB-mediated growth arrest vs CD44 expression. Oncogene 21:1196-1207.

Reisman DN, Sciarrotta J, Wang W, Funkhouser WK, Weissman BE. 2003. Loss of BRG1/BRM in human lung cancer cell lines and primary lung cancers: correlation with poor prognosis.Cancer Res 63:560-566.

Roberts CW, Orkin SH. 2004. The SWI/SNF complex--chromatin and cancer. Nat Rev Cancer 4:133-142.

Rohlin A, Wernersson J, Engwall Y, Wiklund L, Bjork J, Nordling M. 2009. Parallel sequencing used in detection of mosaic mutations: comparison with four diagnostic DNA screening techniques. Hum Mutat 30:1012-1020.

Schneppenheim R, Fruhwald MC, Gesk S, Hasselblatt M, Jeibmann A, Kordes U, Kreuz M, Leuschner I, Martin Subero JI, Obser T, Oyen F, Vater I, Siebert R. 2010. Germline nonsense mutation and somatic inactivation of SMARCA4/BRG1 in a family with rhabdoid tumor predisposition syndrome. Am J Hum Genet 86:279-284.

Shendure J, Ji H. 2008. Next-generation DNA sequencing. Nat Biotechnol 26:1135-1145.

Thomas RK, Nickerson E, Simons JF, Janne PA, Tengs T, Yuza Y, Garraway LA, LaFramboise T, Lee JC, Shah K, O'Neill K, Sasaki H, Lindeman N, Wong KK, Borras AM, Gutmann EJ, Dragnev KH, DeBiasi R, Chen TH, Glatt KA, Greulich H, Desany B, Lubeski CK, Brockman W, Alvarez P, Hutchison SK, Leamon JH, Ronan MT, Turenchalk GS, Egholm M, Sellers WR, Rothberg JM, Meyerson M. 2006. Sensitive mutation detection in heterogeneous cancer specimens by massively parallel picoliter reactor sequencing. Nat Med 12:852-855.

Wang C, Mitsuya Y, Gharizadeh B, Ronaghi M, Shafer RW. 2007. Characterization of mutation spectra with ultra-deep pyrosequencing: application to HIV-1 drug resistance. Genome Res 17:1195-1201.

Wong AK, Shanahan F, Chen Y, Lian L, Ha P, Hendricks K, Ghaffari S, Iliev D, Penn B, Woodland AM, Smith R, Salada G, Carillo A, Laity K, Gupte J, Swedlund B, Tavtigian SV, Teng DH, Lees E. 2000. BRG1, a component of the SWI-SNF complex, is mutated in multiple human tumor cell lines. Cancer Res 60:6171-6177. 
Supplementary Table S1. Read number in forward and reverse for each amplicon within each pool provided by the 454 sequencing platform. The expected number of reads per amplicon per sample is also provided

\begin{tabular}{|c|c|c|c|c|c|c|c|c|}
\hline \multirow[b]{2}{*}{ Amplicon } & \multicolumn{3}{|c|}{ LEFT } & \multicolumn{3}{|c|}{ RIGHT } & \multicolumn{2}{|c|}{$\begin{array}{l}\text { Expected No. reads } \\
\text { per sample }\end{array}$} \\
\hline & FORWARD & REVERSE & TOTAL & FORWARD & REVERSE & TOTAL & LEFT & RIGHT \\
\hline E-2 & 100 & 125 & 225 & 54 & 74 & 128 & 38 & 21 \\
\hline E-3 & 394 & 364 & 758 & 321 & 266 & 587 & 126 & 98 \\
\hline E-4A & 569 & 458 & 1027 & 465 & 390 & 855 & 171 & 143 \\
\hline E-4B & 355 & 260 & 615 & 154 & 129 & 283 & 103 & 47 \\
\hline E-5 & 858 & 441 & 1299 & 632 & 543 & 1175 & 186 & 168 \\
\hline E-6 & 157 & 197 & 354 & 50 & 94 & 144 & 59 & 24 \\
\hline E-7 & 412 & 302 & 714 & 431 & 434 & 865 & 119 & 144 \\
\hline E-8 & 243 & 226 & 469 & 150 & 177 & 327 & 78 & 55 \\
\hline E-9 & 3763 & 4560 & 8323 & 1716 & 3598 & 5314 & 1387 & 886 \\
\hline E-10/11 & 285 & 333 & 618 & 164 & 204 & 368 & 103 & 61 \\
\hline E-12 & 517 & 509 & 1026 & 675 & 648 & 1323 & 171 & 221 \\
\hline E-13 & 12046 & 10157 & 22203 & 19309 & 18065 & 37374 & 3701 & 6229 \\
\hline E-14 & 378 & 234 & 612 & 348 & 328 & 676 & 102 & 113 \\
\hline E-15 & 378 & 0 & 378 & 288 & 4 & 292 & 63 & 49 \\
\hline E-16 & 37 & 864 & 901 & 7 & 799 & 806 & 129 & 115 \\
\hline E-17 & 5708 & 13089 & 18797 & 9477 & 19260 & 28737 & 3133 & 4790 \\
\hline E-18 & 878 & 786 & 1664 & 1336 & 1141 & 2477 & 277 & 413 \\
\hline E-19 & 454 & 0 & 454 & 284 & 0 & 284 & 76 & 47 \\
\hline E-20 & 3636 & 4697 & 8333 & 5042 & 4048 & 9090 & 1389 & 1515 \\
\hline E-21 & 562 & 540 & 1102 & 468 & 715 & 1183 & 184 & 197 \\
\hline E-22 & 515 & 531 & 1046 & 613 & 567 & 1180 & 174 & 197 \\
\hline E-23 & 2837 & 3638 & 6475 & 3125 & 6144 & 9269 & 1079 & 1545 \\
\hline E-24 & 25964 & 12944 & 38908 & 17911 & 9776 & 27687 & 6485 & 4615 \\
\hline E-25 & 544 & 653 & 1197 & 724 & 713 & 1437 & 200 & 240 \\
\hline E-26 & 105 & 100 & 205 & 72 & 90 & 162 & 34 & 27 \\
\hline E-27 & 775 & 745 & 1520 & 743 & 885 & 1628 & 253 & 271 \\
\hline E-28 & 530 & 491 & 1021 & 437 & 94 & 531 & 170 & 89 \\
\hline E-29 & 466 & 439 & 905 & 413 & 156 & 569 & 151 & 95 \\
\hline E-30 & 501 & 529 & 1030 & 603 & 645 & 1248 & 172 & 208 \\
\hline E-31 & 343 & 320 & 663 & 285 & 320 & 605 & 111 & 101 \\
\hline E-32 & 933 & 1178 & 2111 & 788 & 756 & 1544 & 352 & 257 \\
\hline E-33 & 895 & 869 & 1764 & 647 & 385 & 1032 & 294 & 172 \\
\hline E-34 & 536 & 0 & 536 & 580 & 0 & 580 & 89 & 97 \\
\hline Total & 66674 & 60579 & 127253 & 68312 & 71448 & 139760 & 21209 & 23293 \\
\hline
\end{tabular}

John Wiley \& Sons, Inc. 
Supplementary Table S2. Comparison of observed frequencies, obtained by deep sequencing, of SNPs and control mutations and their respective expected frequencies, according to observations from Sanger sequencing. Since tumor samples may have different amounts of normal cell contamination, aneuploidy and LOH, the exact expected frequency for each SNP and mutation control cannot be calculated. Thus, we have calculated the maximum (all samples have LOH, except tumors homozygous for a given SNP) and minimum (no samples have LOH, except the tumors homozygous for the SNP) expected frequencies.

\begin{tabular}{|c|c|c|c|c|c|c|c|c|c|c|c|}
\hline \multirow[b]{2}{*}{$\begin{array}{c}\text { Nucleotide } \\
\text { change }\end{array}$} & \multirow[b]{2}{*}{ Status } & \multicolumn{5}{|c|}{ Left Pool } & \multicolumn{5}{|c|}{ Right Pool } \\
\hline & & $\begin{array}{l}\text { Tumors } \\
\text { with } \\
\text { variants } \\
\text { (Sanger) }\end{array}$ & MEF & MAF & $\begin{array}{c}\% \\
\text { variants }\end{array}$ & $\begin{array}{l}\text { Total } \\
\text { reads }\end{array}$ & $\begin{array}{l}\text { Tumors } \\
\text { with } \\
\text { variants } \\
\text { (Sanger) }\end{array}$ & MEF & MAF & $\begin{array}{c}\% \\
\text { variants }\end{array}$ & $\begin{array}{l}\text { Total } \\
\text { reads }\end{array}$ \\
\hline c. $222-53 \mathrm{~T}>\mathrm{C}$ & SNP & $\mathrm{T} 4^{1}, \mathrm{~T}^{1}$ & 20 & 50 & 22.8 & 394 & - & 0 & 0 & 0 & 321 \\
\hline c. $356-14 \mathrm{~A}>\mathrm{G}$ & SNP & $\mathrm{T} 4, \mathrm{~T} 5$ & 17 & 33.3 & 15.7 & 708 & - & 0 & 0 & 0 & 772 \\
\hline c.805_806delCC & $\begin{array}{l}\text { Control } \\
\text { mutation }\end{array}$ & $\begin{array}{l}\text { H522 cells } \\
\quad(1 / 50)\end{array}$ & 0.15 & 0.3 & 0 & 1162 & H522 cells & 7 & 14 & 5.3 & 1119 \\
\hline c. $1413 \mathrm{G}>\mathrm{A}$ & SNP & $\mathrm{T} 4, \mathrm{~T} 5$ & 17 & 33.3 & 19 & 279 & - & 0 & 0 & 0.9 & 224 \\
\hline c. $1509 A>G$ & SNP & $\mathrm{T} 4, \mathrm{~T} 5$ & 17 & 33.3 & 16.6 & 7389 & - & 0 & 0 & 0.04 & 4918 \\
\hline c. $1524 \mathrm{~T}>\mathrm{C}$ & SNP & $\begin{array}{l}\text { T1, T2 }{ }^{1}, \\
\text { T4, T5 }\end{array}$ & 40 & 75 & 48.3 & 7354 & $\mathrm{~T} 9, \mathrm{~T} 11^{1}$ & 17 & 33.3 & 20 & 4919 \\
\hline c. $1761+29 \mathrm{G}>\mathrm{A}$ & SNP & $\mathrm{T} 4, \mathrm{~T} 5$ & 17 & 33.3 & 12.3 & 381 & - & 0 & 0 & 0 & 312 \\
\hline c. $1762-37 \mathrm{~T}>\mathrm{C}$ & SNP & $\begin{array}{l}\mathrm{T} 1, \mathrm{~T}^{1} \\
\mathrm{~T} 4,5^{1}\end{array}$ & 40 & 71 & 46 & 287 & $\mathrm{~T}_{1}{ }^{1}$ & 9 & 29 & 13 & 177 \\
\hline c. $2123+12 C>T$ & SNP & $\mathrm{T} 4, \mathrm{~T} 5$ & 17 & 33.3 & 22 & 578 & - & 0 & 0 & 0 & 655 \\
\hline c. $2290 \mathrm{~T}>\mathrm{A}$ & $\begin{array}{l}\text { Control } \\
\text { mutation }\end{array}$ & $\begin{array}{c}\mathrm{H} 2126 \\
\text { cells }\end{array}$ & 7 & 14 & 7 & 711 & $\begin{array}{l}\mathrm{H} 2126 \text { cells } \\
\quad(1 / 50)\end{array}$ & 0.15 & 0.3 & 0.14 & 732 \\
\hline c. $3954 \mathrm{C}>\mathrm{T}$ & SNP & - & 0 & 0 & 0.5 & 905 & $\mathrm{~T} 7$ & 8.3 & 27 & 16 & 493 \\
\hline c. $4485 \mathrm{C}>\mathrm{T}$ & SNP & $\mathrm{T} 1$ & 8.3 & 17 & 6 & 634 & - & 0 & 0 & 0 & 588 \\
\hline c. $4788 \mathrm{~T}>\mathrm{C}$ & SNP & $\begin{array}{c}\text { T1, T2, } \\
\text { T4, T5 }{ }^{1}, \\
\text { T6 }\end{array}$ & 42 & 85 & 59 & 1341 & $\mathrm{~T}^{1}, \mathrm{~T} 11$ & 18 & 43 & 20.5 & 919 \\
\hline
\end{tabular}

${ }^{1}$ Indicates that the tumor is homozygous for the polymorphism. Given the presence of normal cell contamination in all tumor specimens, the homozygous or heterozygous nature of a SNP can be determined. T, Tumor identification. MEF, Minimum expected frequency; MAF, Maximum expected frequency. 
Supplementary Methods 1. List of SMARCA4 amplicons obtained by intron-primed high-fidelity PCR of tumor genomic DNA. Amplicon names are designated by the name of the exons (E, exon number), and their size is indicated in base pairs (bp). Letters in bold indicate the priming sequences used for amplification. Exon 4 was split into two amplicons, $A$ and B; exons 10 and 11 were amplified together.

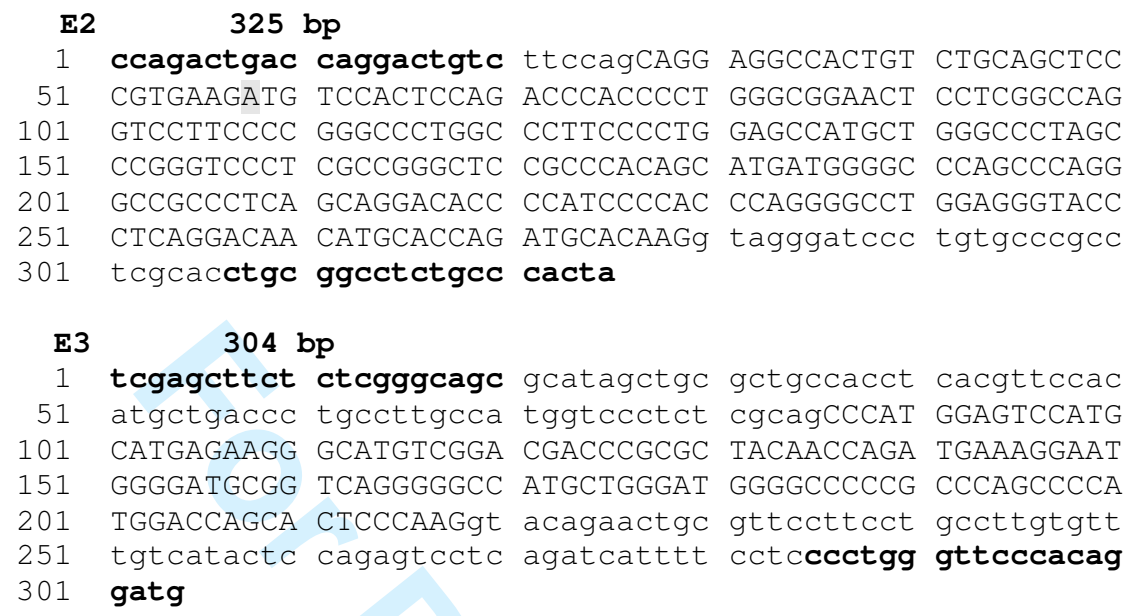

John Wiley \& Sons, Inc. 


\section{Rodriguez-Nieto et al.}

201 tccgaaagg gccttgtca ccaacactgc

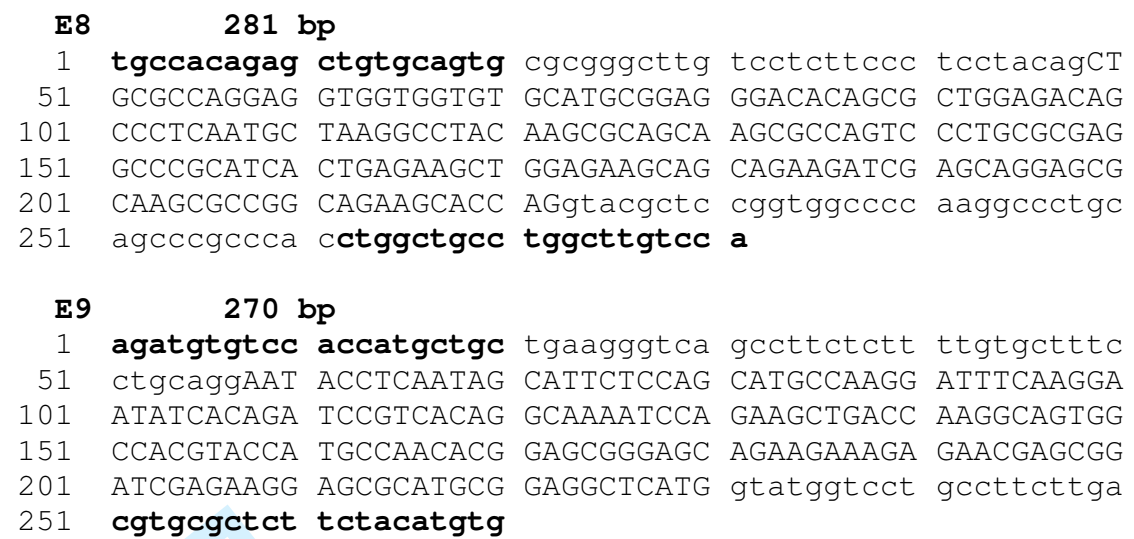


E17 $135 \mathrm{bp}$

gactctcatt tccttgttcc atcagaACGC TGTCCAACTG GGCGTACGAG

51 TTtGACAAGT GGGCCCCCTC CGTGGTGAAG GTGTCTTACA Aggtaggtca

101 cagccactga ggtttcctct ctt gctacgg aggtg

E18 $\quad 180 \mathrm{bp}$

1 ccggctccaa aagccgagct gtgcatcctg cttcccttgc agGGATCCCC

51 AgCAgCAAGA CGgGCCTtTG TCCCCCAGCT CCGGAGTGGG AAgtTCAACG

101 TCTTGCTGAC GACGTACGAG TACATCATCA AAGACAAGCA CATCCTCGCC

151 AAGgtaacgt gtccctgtgg gaaatgccag

E19 324 bp

1 tgccetgatt geccactctg gggcecgcag ATCCGTTGGA AGTACATGAT

51 TGTGGACGAA GGTCACCGCA TGAAGAACCA CCACTGCAAG CTGACGCAGG

101 TGCTCAACAC GCACTATGTG GCACCCCGCC GCCTGCTGCT GACGGGCACA

151 CCGCTGCAGA ACAAGCTTCC CGAGCTCTGG GCGCTGCTCA ACTTCCTGCT

201 GCCCACCATC TTCAAGAGCT GCAGCACCTT CGAGCAGTGG TTTAACGCAC

251 CCTTTGCCAT GACCGGGGAA AAGgtgggtt tgcccagctg tgcccatgct

301 gacggttcca ggtgcggctg gett

E20 $229 \mathrm{bp}$

1 cccacatccg caccttctag tgagacctct gtcgcectcc tttggaggta

51 acgcttgctt ctcctgtctt gggggcttcc agGTGGACCT GAATGAGGAG

101 GAAACCATTC TCATCATCCG GCGTCTCCAC AAAGTGCTGC GGCCCTTCTT 151 GCTCCGACGA CTCAAGAAGG AAGTCGAGGC CCAGTTGCCC GAAAAggtga

201 tggagttttg aggggagcca ccagtgaag

E21 246 bp

1 accttgggcc ctcgtgagca ttatgtgtCC cCtgcagGTG GAGTACGTCA

51 TCAAGTGCGA CATGTCTGCG CTGCAGCGAG TGCTCTACCG CCACATGCAG

101 GCCAAGGGCG TGCTGCTGAC TGATGGCTCC GAGAAGGACA AGAAGgtggg

151 ccccagagtc ccccaactgc attccccact gggtgtccaa ggccggcagc

201 gtggcaggca gagcagagcg tgctctgacc atcgggtcat gatctg

E22 $151 \mathrm{bp}$

1 ccatttgggt ccctctcatc tgccttccag GGCAAAGGCG GCACCAAGAC

51 CCTGATGAAC ACCATCATGC AGCTGCGGAA GATCTGCAAC CACCCCTACA 101 TGTTCCAGCA CATCGAGgtg agcCCgCCgC ggctgggacg gctcaggccc $151 \mathrm{t}$

\section{E23 $144 \mathrm{bp}$}

1 cetgtcactg acccetctct ccttgccttg cagGAGTCCT TTTCCGAGCA

51 CTTGGGGTTC ACTGGCGGCA TTGTCCAAGG gtgagaagct tcccaactgg

101 atggggtggg caggtggtcc acccagaggt tttctgtcgt tttg

\section{E24 $248 \mathrm{bp}$}

1 gtttaacatc ctgegccttc tctcctgcet cctccacact ccagGCTGGA

51 CCTGTACCGA GCCTCGgGTA AATTTGAGCT TCTTGATAGA ATTCTTCCCA

101 AACTCCGAGC AACCAACCAC AAAGTGCTGC TGTTCTGCCA AATGACCTCC

151 CTCATGACCA TCATGGAAGA TTACTTTGCG TATCGCGGCT TTAAATACCT

201 CAGGCTTGAT Ggtgagtatg agccagtgag gcgtttctta cagggttt

E25 $330 \mathrm{bp}$

1 gtccccactc tacccctgag gtcaccccgc tgaccetgtt ctcctctgtg 51 cccgtcaggA ACCACGAAGG CGGAgGACCG GGgCATGCTG CTGAAAACCT 101 TCAACGAGCC CGGCTCTGAG TACTTCATCT TCCTGCTCAG CACCCGGGCT 151 GGGGGGCTCG GCCTGAACCT CCAGTCGGCA GACACTGTGA TCATtTtTGA 201 CAGCGACTGG AATCCTCACC AGgtaaaagC gggccgggCC cCaggtcgag 251 gagaaggaag ggggtgcctg caaaacctcg aggagacggc cctggcttga 301 gggtcctcca gcctcctcca cattgtcttg 


\title{
18 Rodriguez-Nieto et al.
}




\section{Page 19 of 19}

Human Mutation

Deep sequencing and SMARCA4 mutations in lung cancer

2

3

4

5

6

7

8

9

10

11

12

13

14

15

16

17

18

19

20

21

22

23

24

25

26

27

28

29

30

31

32

33

34

35

36

37

38

39

40

41

42

43

44

45

46

47

48

49

50

51

52

53

54

55

56

57

58

59

60

John Wiley \& Sons, Inc. 